\title{
Increasing Students' Learning Outcomes Through the Implementation of Outing Class Strategy in Natural Science Subject
}

\author{
Purdiyanto*, Eva Istapra, Raden Gamal Tamrin Kusumah, Ahmad Walid \\ Doctor of Education, Universitas Bengkulu, Indonesia \\ *Corresponding author. Email: dongawalid19@gmail.com
}

\begin{abstract}
This study aims to describe the implementation of the outing class learning strategy and to find out its effects on students' learning outcomes in science subject. This qualitative study uses students in $5^{\text {th }}$ grade as the primary data, and the class teachers who teach science subjects as the secondary data. Data collection techniques used are observation, interview and documentation. From the results of observations in the field the outing class strategy has been carried out by the teachers at the place where the research was carried out in accordance with the steps in the learning strategy. The learning process that has been done is starting from planning the lesson plan, syllabus, methods, media and equipment used, implementation is done outside the classroom and after learning is done, there is an evaluation of learning outcomes. Based on the results of interviews, observation and documentation, it can be seen that by using the outing class strategy, elementary school teachers can improve students' science learning outcomes. This can be seen from the student's science learning outcomes that improved after learning outing classes.
\end{abstract}

Keywords: Outing Class Learning Strategies, Learning Outcomes, Science Subject.

\section{INTRODUCTION}

Learning process is an intensive interaction process between the various components of the learning system, including teachers, students, learning materials, and the environment. The learning process in each educational unit is organized in an interactive, inspiring, fun, challenging, motivating students to participate in activities, and provides sufficient space for initiative, creativity, and independence according to the talents, interests, and physical and psychological development of students [1]-[3].

Classroom action research needs to be conducted to keep the learning activities run effectively and efficiently. Classroom action research is an examination of learning activities in the form of an action, which is deliberately raised and occurs in a class simultaneously [4]-[9].

One way to stimulate students' motivation during the learning process is by applying appropriate teaching strategy which can make students as subjects who try to dig by themselves, solve their own problems from a concept being studied, while teachers act more as motivators and facilitators. Strategy is the process of determining a plan that focuses on the long-term goals of the school, along with the preparation of ways or efforts to achieve these goals [10].

Learning strategy is an approach to managing activities, by integrating the sequence of activities, how to organize learning and learning materials, tools and materials and the time used in the learning process, to achieve predetermined learning objectives, effectively and efficiently. The learning strategy contains the question of how to convey the content of the lesson? Is the subject matter presented to students either individually or in groups? After the material is selected, there are other questions, who will teach it? Teachers individually or in teams, how do teachers motivate students so that students participate, how teachers must manage the class so that lessons run properly [11]-[15].

Furthermore, the operational components of a learning strategy are in the form of a sequence of activities, methods, models, learning media and time. Method is a method used to achieve predetermined goals. In teaching and learning, the method required by teachers and its use vary according to the goals to be 
achieved after teaching ends [5]. The various teaching methods include: lectures, expository, question and answer, discovery, discussion methods, demonstrations, field trip methods and others. Learning model can be interpreted as a plan or pattern used in compiling the curriculum, organizing student material and giving instructions to teachers in the classroom in teaching settings or other settings. Choosing a teaching model, must adjust to the existing reality and the existing classroom situation, as well as the view of life that will result from the process of collaboration between teachers and students [16]-[21].

Specifically, outing class learning strategy is a learning that is carried out outside the room or class which aims to equip students' skills and develop their abilities. The outing class strategy is active, innovative, creative and fun. Learning strategies should always emphasize the active students in every learning process. Innovative means every lesson must provide something new, different and always attract students' interest. Creative means each learning must generate interest in students to produce something or be able to solve a problem using methods, techniques or methods that are mastered by the students themselves obtained from the learning process [22]-[26].

Outing class learning strategies are very appropriate to be applied to elementary school children because most of them like games related to the surrounding environment so that they make children enjoy the learning that is carried out because when children can enjoy the learning being carried out, of course they are easier and faster to absorb learning material [22]-[26]

Along with the professional responsibilities of teachers in the learning process, in carrying out learning activities each teacher is required to always prepare everything related to the learning program that will take place. The goal is that learning activities can run effectively and efficiently, namely the final goal which is expected to be mastered by all students [27]-[29].

One of the outing class activities that is often done is to visit the zoo, beach and swimming pool, and playgorund. Learning activities with an outing class strategy with contextual learning can also make visits to health centers, police stations, post offices, fire brigade offices, companies and so on. During outing class activities the children can play while learning. Through outing class activities, the children also do not only sit quietly listening to the teacher's explanation but also move actively and freely according to their ability to explore the environment they are visiting [30].

Several past research results indicate outing class learning strategies can help in fostering interest in learning in children. In the new normal era, this strategy is suitable to be applied in learning because it can eliminate learning boredom in children during the
Covid-19 pandemic, provided that students are required to adhere to health protocols [31]-[33].

\section{METHOD}

This qualitative study uses evaluative research methods. Qualitative research is descriptive research and tends to use analysis. Process and meaning (subject perspective) are emphasized more in qualitative research. The theoretical basis is used as a guide so that the research focus is in accordance with the facts in the field. In addition, this theoretical basis is also useful for providing an overview of the research background and as material for discussion of research results. There are fundamental differences between the role of theoretical foundations in quantitative research and qualitative research. In quantitative research, research departs from theory to data, and ends in acceptance or rejection of the theory used; Meanwhile, in qualitative research the researcher departs from the data, makes use of existing theories as explanatory material, and ends with a "theory". The location of this research is $5^{\text {th }}$ grade at Public Elementary School 14 Seluma. The research was carried out on July 30, 2019 to September 10, 2019.

This type of research is field research. Researchers made direct observations following outing class activities carried out by inclusive students in order to obtain research results that were in accordance with the conditions in the environment. The reason for this research was only for all inclusive student in Public Elementary School 14.

Sources of data in this study include primary and secondary data. The primary data sources were the principal, classroom teachers, accompanying teachers for inclusion students, and parents of guardians of students at Public Elementary School 14 Seluma. Secondary data sources are documents, schedule of outing class activities, photos of outing class learning activities at Public Elementary School 14 Seluma.

Data collection techniques are methods used by researchers to collect data [34], [35]. In this study, data collection techniques used observation, interviews, and documentation. The data analysis technique used in this study was qualitative data analysis. Miles and Huberman. Sugiyono argued that activities in qualitative data analysis were carried out continuously until completion, so that the data was saturated [36]. Activities in data analysis, namely data reduction, display data, and conclusion drawing / verification. In this study using triangulation techniques and techniques.

Information triangulation was carried out during the study from sources so that in the end only valid data were used to achieve the research results [37]. The method of triangulation technique is done by checking the information from interviews with documentation and observation. 


\section{RESULT AND DISCUSSION}

\subsection{Pre Cycle}

As presented in Table 1, 2 students $(22.22 \%)$ were happy in following the process of teaching and learning, 2 students $(22.22 \%)$ participated in the process learning takes place, 1 student $(11.11 \%)$ is calm or not rowdy learning process, 2 students $(22.22 \%)$ enthusiasm in following the process learning, 1 student $(11.11 \%)$ is diligent in the learning process, and 1 student $(11.11 \%)$ was brave to express his/her ideas during the teaching and learning process. From these facts it seems that student's motivation is still low in learning the subjects of Natural Sciences (IPA).

Table 1. Observed Student's Motivation

\begin{tabular}{|c|c|c|c|c|c|c|c|c|}
\hline \multirow[t]{2}{*}{ No } & \multirow[t]{2}{*}{ Students } & \multirow[t]{2}{*}{ Sex } & \multicolumn{6}{|c|}{ Observed Aspects } \\
\hline & & & Happines & $\begin{array}{c}\text { Participatio } \\
\text { n }\end{array}$ & Calm & Spirit & Diligent & $\begin{array}{l}\text { Delivering } \\
\text { Idea }\end{array}$ \\
\hline 1 & Siswa a & $\mathrm{M}$ & $\sqrt{ }$ & & & $\sqrt{ }$ & & \\
\hline 2 & Siswa b & $\mathrm{M}$ & & & & & & $\sqrt{ }$ \\
\hline 3 & Siswa c & M & & $\sqrt{ }$ & & $\sqrt{ }$ & & \\
\hline 4 & Siswa d & $\mathrm{M}$ & & & & & & \\
\hline 5 & Siswa e & $\mathrm{M}$ & & & $\sqrt{ }$ & & $\sqrt{ }$ & \\
\hline 6 & Siswa f & $\mathrm{F}$ & & & & & & \\
\hline 7 & Siswa g & $\mathrm{F}$ & $\sqrt{ }$ & $\sqrt{ }$ & & & & \\
\hline 8 & Siswa h & $\mathrm{F}$ & & & & & & \\
\hline 9 & Siswa i & $\mathrm{M}$ & & & & & & \\
\hline & Sum & & 2 & 2 & 1 & 2 & 1 & 1 \\
\hline & Percentage & & $22,22 \%$ & $22,22 \%$ & $11,11 \%$ & $22,22 \%$ & $11,11 \%$ & $11,11 \%$ \\
\hline
\end{tabular}

\subsection{Cycle I}

Some preparation in cycle I include Creating a learning syllabus, developing learning plans and strategies, preparing and arranging material, making learning motivation sheets, and preparing lesson plan with the Outing Class strategy. Meeting I was held on August 20, 2020, and meeting II was implemented on August 21, 2020. Some indicators that need to be achieved by students are: identify how to care for and raise pets, explains how to care for and raise animals, demonstrate how to care for and keep pets (in meeting 1), explain the understanding symbiosis of mutualism, parasitism and commensalism in an environmental way school (in meeting 2).

The data of the first and second meeting $\mathrm{i}$ in cycle I revealed that 4 students showed happy (44.44\%), 5 students participated $(55.55 \%), 4$ students were calm (44.44\%), 3 students were enthusiasm (33.33\%), 3 students were diligent in learning activities (33.33\%), and 3 students were able to express their ideas $(33.33 \%)$.

\subsection{Cycle II}

The preparation in cycle are are the same with what have been done in cycle 1 . The implementation of cycle II was carried out using a cooperative strategy bamboo dancing type. the first meeting was held on 12 September 2020 and the second meeting was held on
November 30, 2013. At meeting I and 2 researchers applied the Outing Class strategy. As for indicators that must be achieved were explaining the food chain process, mentioning the animals which include consumers 1, consumers 2 and consumers 3 and describing the observed food chain in the rice fields (first meeting), mentioning examples and properties of solid, liquid and gas, explaining the properties of solid, liquid and gas and identifying differences in solid, liquid and gas (second meeting).

The Outing Class strategy has been implemented in two cycles which each cycle consisted of two meeting. There are indicators of motivation that must be considered among other researchers: 1) Pleasure 2) Student participation 3) calm 4) Passion 5) Perseverance 6) expressing ideas.

From the results of observations made by using learning Outing Class strategy can increase student motivation as shown by the data the results of observation of student learning motivation, pre-cycle results to cycle II increased.

\section{CONCLUSION}

From the results of the research that has been done, the following conclusions can be drawn:

Based on observations, interviews and documentation, the outing class strategy has been carried out by teachers in $5^{\text {th }}$ grade Public Elementary 
School 14 Seluma according to the steps in the learning strategy. The learning that has been done is starting from planning the lesson plan, syllabus, methods, media and equipment used, implementation is done outside the classroom and after learning is done, there is an evaluation of learning outcomes.

Based on the results of interviews, observation and documentation, it can be seen that by using the outing class strategy, Public Elementary School 14 teachers can improve students' science learning outcomes. This can be seen from the student's science learning outcomes that improved after outing class learning was carried out.

\section{REFERENCES}

[1] C. Semiawan, Yufiarti, and T. I. Setiawan, Belajar dan pembelajaran dalam taraf Pendidikan Usia Dini: Pendidikan Prasekolah dan Sekolah Dasar. Jakarta: Prenhallindo, 2002.

[2] E. Hangestiningsih, H. M. Zulfiati, and A. B. Johan, "Pengantar Ilmu Pendidikan," Diktat Pengantar Ilmu Pendidik., 2015, doi: http://dx.doi.org/10.1016/j.msec.2016.03.021.

[3] H. Suyono, "Belajar dan pembelajaran Teori dan konsep Dasar," Bandung PT Remaja Rosdakarya, 2011.

[4] Z. Aqib, E. Diniati, S. Jaiyaroh, and K. Khotimah, Penelitian Tindakan Kelas Untuk Guru SD, SLB, dan TK. Bandung: CV. Yrama Widya, 2011.

[5] I. Ismiyati, "Peningkatan Prestasi Dan Motivasi Belajar Ppkn Siswa Kelas Viii A Smp Negeri 2 Gedangsari - Gunungkidul Melalui Pembelajaran Group Investigation," Sch. J. Pendidik. dan Kebud., vol. 5, no. 1, p. 39, Jan. 2015, doi: 10.24246/j.scholaria.2015.v5.i1.p3956.

[6] A. Alidawati, "Meningkatkan Hasil Belajar Siswa Dengan Menggunakan Media Gambar Berupa Rumah Adat Tentang Keragaman Budaya Di Indonesia Pada Pelajaran IPS Di Kelas V SD Negeri 03 Kota Mukomuko," Indones. J. Soc. Sci. Educ., vol. 1, no. 1, pp. 7884, Jan. 2019.

H. B. Masniwati, "Upaya Meningkatkan Aktifits dan Hasil Belajar Peserta Didik kelas IV SD Negeri 45 Mataram Semester Satu Tahun Pelajaran 2017/2018 Melalui Penerapan Pendekatan Cooperative Learning (CL) Tipe Jigsaw," J. Ilm. Mandala Educ., vol. 4, no. 1, pp. 22-30, 2018, doi: 2442-9511.
[8] R. Riswanto and N. A. K. Dewi, "Peningkatan Keterampilan Proses Sains Melalui Pembelajaran Berbasis Laboratorium Untuk Mewujudkan pembelajaran Berkarakter," J. Ris. dan Kaji. Pendidik. Fis., vol. 4, no. 2, p. 60, Nov. 2017, doi: 10.12928/jrkpf.v4i2.8164.

[9] F. Yasmin and E. Erni, "Metode Pembelajaran Imajinatif Dalam Meningkatkan Hasil Belajar Mengarang Bahasa Indonesia Dengan Menggunakan Media Lagu," vol. 3, no. 1, pp. 238-245, 2017

[10] D. E. Prasasti, H. D. Koeswanti, and S. Giarti, "Peningkatan Keterampilan Berpikir Kritis Dan Hasil Belajar Matematika Melalui Model Discovery Learning Di Kelas Iv Sd," $J$. Basicedu, vol. 3, no. 1, pp. 174-179, Apr. 2019, doi: 10.31004/basicedu.v3i1.113.

[11] M. K. Abadi, H. Pujiastuti, and L. D. Assaat, "Development of Teaching Materials Based Interactive Scientific Approach towards the Concept of Social Arithmetic for Junior High School Student," 2017, doi: 10.1088/17426596/812/1/012015.

[12] J. Vennix, P. den Brok, and R. Taconis, "Do outreach activities in secondary STEM education motivate students and improve their attitudes towards STEM?," Int. J. Sci. Educ., vol. 40, no. 11, pp. 1263-1283, Jul. 2018, doi: 10.1080/09500693.2018.1473659.

[13] S. Suminem, "Meningkatkan Hasil Belajar Fisika Dalam Materi Gerak Melingkar Melalui Implementasi Lesson Study Menggunakan Model Keterampilan Proses Sains Siswa Man 2 Pontianak," J. Pendidik. Mat. dan IPA, vol. 4, no. 2, Nov. 2016, doi: 10.26418/jpmipa.v4i2.17589.

[14] Z. Zulkifli, "Strategi Kepala Sekolah Dalam Meningkatkan Kompetensi Profesional Guru Pada Sma Negeri 1 Peukan Bada Kabupaten Aceh Besar," J. Ilm. Didakt., 2014, doi: 10.22373/jid.v14i2.505.

[15] M. A. Tanjung, F. Azmi, and S. Siahaan, "Headmaster Policy Of Senior Islamic School To Increas Teacher Profesionalism At State Senior Islamic School 2 Model Medan," Int. J. Lang. Res. Educ. Stud., 2017, doi $10.30575 / 2017081210$.

[16] A. Sewang and A. Halik, "Model Manajemen Pembelajaran Pendidikan Islam Berbasis Masalah: Studi Kasus pada Jurusan Tarbiyah dan Adab IAIN Parepare," JPPI (Jurnal Pendidik. Islam Pendekatan Interdisipliner), 
vol. 3, no. 1, pp. 1-15, Jun. 2019, doi: 10.36915/jpi.v3i1.47.

[17] Akhmad Yazidi, "Memahami model-model pembelajaran dalam kurikulum 2013," J. Bahasa, Satra, dan Pembelajarannya, 2014.

[18] Bruce Joyce, Models Of Teaching, Paperback. PHI Learning Private Limited, 2009.

[19] Visitaeva M.B., Latipova L.N., Egorova E.A., Getmanova E.S, Ermakov V.P., Chirkova E.A., "Method of teaching evidence-based processes," opcion, vol. 34, no. 87, p. 2, 2018.

[20] H. Jung and E. Choi, "The importance of indirect teaching behaviour and its educational effects in physical education," Phys. Educ. Sport Pedagog., 2016, doi: 10.1080/17408989.2014.923990.

[21] E. Pakarinen, M. K. Lerkkanen, A. M. Poikkeus, M. Siekkinen, and J. E. Nurmi, "Kindergarten teachers adjust their teaching practices in accordance with children's academic pre-skills," Educ. Psychol., vol. 31, no. 1, pp. 37-53, 2011, doi: 10.1080/01443410.2010.517906.

[22] Z. Okan, "Edutainment: Is learning at risk?," $B r$. J. Educ. Technol., vol. 34, no. 3, pp. 255-264, 2003, doi: 10.1111/1467-8535.00325.

[23] S. Sutarto, I. Indrawati, J. Prihatin, and P. A. Dwi, "Geometrical Optics Process Image-Based Worksheets for Enhancing Students' HigherOrder Thinking Skills and Self-Regulated Learning," J. Pendidik. IPA Indones., vol. 7, no. 4, pp. 376-382, Dec. 2018, doi: 10.15294/jpii.v7i4.14563.

[24] J. Sapri, N. Agustriana, and R. G. T. Kusumah, "The Application of Dick and Carey Learning Design toward Student's Independence and Learning Outcome," in Proceedings of the International Conference on Educational Sciences and Teacher Profession (ICETeP 2018), Apr. 2019, pp. 218-222, doi: 10.2991/icetep-18.2019.53.

[25] Rusmansyah, L. Yuanita, M. Ibrahim, Isnawati, and B. K. Prahani, "Innovative chemistry learning model: Improving the critical thinking skill and self-efficacy of pre-service chemistry teachers," J. Technol. Sci. Educ., vol. 9, no. 1, pp. 59-76, 2019, doi: 10.3926/jotse.555.

[26] B. L. Boyd, K. E. Dooley, and S. Felton, "Measuring Learning In The Affective Domain Using Reflective Writing About A Virtual
International Agriculture Experience," J. Agric. Educ., 2006, doi: 10.5032/jae.2006.03024.

[27] N. Wulandari and N. Wulandari, "Analisis Kemampuan Literasi Sains Pada Aspek Pengetahuan Dan Kompetensi Sains Siswa Smp Pada Materi Kalor," Edusains, 2016, doi: 10.15408/es.v8i1.1762.

[28] S. Ria Febu Khoerunnisa, N. Murbangun, "Pengembangan Modeul IPA Terpadu Etnosains untuk Menumbuhkan Minat Kewirausahaan," J. Innov. Sci. Educ., 2012.

[29] T. Widiyaningtyas and A. Widiatmoko, "Media Pembelajaran Berbasis Web Pada Mata Pelajaran Kimia," J. Teknol., vol. 21, pp. 47-51, 2014.

[30] Julaila, "Upaya Meningkatkan Hasil Belajar IPA Siswa Kelas IV SDN 01 Mukomuko Menggunakan Media Torso," IJIS Edu Indones. J. Integr. Sci. Educ., vol. 1, no. 1, pp. 51-62, 2019, doi: 10.29300/ijisedu.v1i1.1405.

[31] P. Prayitno and M. F. F. Mardianto, "Peningkatan Hasil Evaluasi Pembelajaran Daring Saat Pandemi Covid-19 Berdasarkan Media Powerpoint Interaktif Dinas Pendidikan Kabupaten Kediri , SMPN 1 Mojo , Kediri , Indonesia Departemen Matematika , Fakultas Sains dan Teknologi , Universitas Airlangga," MUST J. Math. Educ. Sci. Technol., vol. 5, no 2, pp. 171-181, 2020.

[32] Y. Fitriyani, I. Fauzi, and M. Z. Sari, "Motivasi Belajar Mahasiswa Pada Pembelajaran Daring Selama Pandemik COVID-19," Profesi Pendidik. Dasar, 2020, doi: 10.23917/ppd.v7i1.10973.

[33] M. Salehudin, "Dampak Covid-19: Guru Mengadopsi Media Sosial Sebagai E-Learning Pada Pembelajaran Jarak Jauh," J. MUDARRISUNA, vol. 10, no. 1, pp. 1-16, 2020.

[34] D. M. A. Lexy J. Moleong, "Metodologi Penelitian Kualitatif (Edisi Revisi)," PT. Remaja Rosda Karya, 2019, doi: 10.1016/j.carbpol.2013.02.055.

[35] Margono, Metodologi Penelitian Pendidikan. Jakarta: Rineka Cipta, 2009.

[36] Sugiyono, Metode Penelitian Kuantitatif Kualitatif dan R\&D. Bandung: Alfabeta, 2015.

[37] S. Arikunto, Metode Penelitian Kuantitatif, Kualitatif, dan Kombinasi (Mixed Methods) Bandung: Alfabeta, 2014. 